\title{
KINERJA BADAN AKREDITASI NASIONAL- PERGURUAN TINGGI \\ (BAN-PT); RELEVANSINYA DENGAN FUNGSI \\ PEMBINAAN PENINGKATAN KUALITAS PROGRAM STUDI
}

\author{
M. Nasrun ${ }^{1}$
}

\begin{abstract}
This research aims at describing the performance of the BAN-PT (The National Accreditation Board for Higher Education) in line with its function to guide the imporvement of the study program quality in the six focuses as follows: (1) the potency of criteria as an evaluation standard; (2) potency of choosing and applying techniques and tools; (3) potency of process stages in accommodating the need for data to measure quality and the relavance of study program (filling borang workshop I, visitation, and workshop II); (4) appli-cation of the evaluation criteria; (5) achievement of the target of study program and (6) improvement of quality of the accredited study program quantitatively.
\end{abstract}

Keyword: performance of the BAN-PT, relevance, guidance and quality

Sejujurnya, kualitas dan relevansi pendidikan nasional masih rendah, mana-kala menyimak hasil penelitian dan fakta yang dikemukakan berikut.

(1) Studi the Third International Mathematic and Science Study Repeat (TIMS-R) mendudukkan siswa SLTP Indonesia pada peringkat ke 32 untuk IPA, dan ke 34 untuk Matematika dari 38 negara Asia, Australia dan Afrika yang disurvai (Tim Broad-Based Education Deppenas, 2000: 2);

(2) Mempertahankan 60.000 tenaga kerja asing dengan biaya $\$ 3$ miliyar, sementara

\footnotetext{
${ }^{1}$ M. Nasrun adalah dosen Jurusan Ilmu Pendidikan FKIP-UNTAN Pontianak
} 
(3) Laporan Asia Week, edisi 23 Mei 1997 tentang Asia's Best Universities (terma-suk Selandia Baru dan Australia) menempatkan peringkat ITB, UI, UGM, Unair, dan Undip pada urutan ke-19, 32, 37, 38, dan 42 dari 50 PT yang diakreditasi. Kelima PT tersebut, masing-masing hanya masuk dalam kategori C, D, D, D, D (Supriyoko, 1997; dan Segereg, 1998).

Kondisi tersebut, telah mendorong pemerintah memperbaiki citra perguruan tinggi. Akhirnya, tanggal 15 Desember 1994 dibentuk Badan Akreditasi Nasional Perguruan Tinggi (BAN-PT), melalui Kepmendikbud No. 0326/U/1994, dengan pembaharuan Kepmendikbud No. 187/U/1998.

Kondisi sistem yang ada menghadapkan pemerintah pada pilihan sulit. Ren-dahnya kualitas dan relevansi output pendidikan telah menimbulkan pangangguran, tetapi di pihak lain partisipasi perguruan tinggi dalam pembangunan masih rendah, yakni 2,3\% (tahun 1985), jauh dari negara Asia lainnya, seperti Malaysia 5,1\%, Taiwan 10,1\% (Harsono, 1998).

Lebih disesalkan, asumsi masyarakat (umumnya) terhadap perguruan tinggi sebagai prestise dan status sosial telah memperkuat arus masuk. Sementara, elit tertentu, menganggap arus tersebut sebagai kesempatan bisnis yang dimanfaatkan untuk membangun perguruan tinggi tanpa memperhatikan persyaratan yang mem-pengaruhi kualitas proses input-output.

Menurut Sulistyo (1997), rendahnya kualitas PT disebabkan kurangnya moti-vasi membaca dosen. Hal tersebut nampak pada kurangnya minat beli buku

(mengingat rendahnya gaji peneliti dan mahalnya harga buku), dan rendahnya ketersediaannya di perpustakaan. Diilustrasikan, bahwa bukubuku perpustakaan UI masih jauh di bawah perpustakaan rakyat (di tingkat kecamatan) AS.

Sebab lainnya, adalah rendahnya kualitas dosen dari segi akademik. Menurut data Dardjowidjojo (1998), Indonesia masih mempekerjakan $75 \%$ dosen tamatan $\mathrm{S} 1$, dan $25 \%$ dosen yang berpendidikan S2 dan S3. Menurut data akreditasi tahun 1997/ 1998 telah tejadi kemajuan. Seluruh dosen 1.035 program studi dari 47 perguruan tinggi negeri yang memiliki ijazah S2 dan S3 telah meningkat menjadi 41,14\%; dan 11,20\% (Depdikbud, 2000b). Berarti,.sudah mencapai $52,31 \%$. Namun, dibandingkan Yale dengan 94\% dosennya bergelar Ph.D, Harvard (100\% Ph.D), dan universitas yang biasa-biasa saja (Seton Hall, Idaho State, dan Taledo, masing-masing sudah 89\%, 85\%, dan 85\%), tenaga kependidikan Indonesia masih jauh di bawah Amerika. 
Tentunya, kualitas PT nasional tidak terlepas dari kualitas pendidikan dasar (SLTP), seperti yang ditunjukkan oleh hasil studi the Third International Mathematic and Science Study Repeat (TIMS-R terdahulu. Dengan peringkat ke-32 untuk IPA, dan ke-34 untuk Matematika dari 38 negara Asia, Australia dan Afrika yang disurvai, sangatlah rasional jika UI menduduki peringkat ke 32 dari perguruan tinggi di Asia, Australia, dan Selandia Baru.

Selanjutnya, relevansi sebagai variabel yang berhubungan dengan masalah perguruan tinggi harus dilihat dari sudut pandang yang lebih luas. Menurut UNESCO, Being relevant means getting together with the politicans, the world of work, and other levels of the education system (Suhendro. 1998b). Makna relevansi PT selalu dikaitkan dengan sistem politik, skil dan keahlian dunia kerja dan kesinam-bungannya dengan proses pembelajaran pada jenjang sistem pendidikan.

Sehubungan dengan itu, (PPRPLP \& PP Unibraw) mengemukakan empat parameter relevansi pendidikan. (1) Employability, memberikan kemampuan yang dapat digunakan, sesuai dengan kebutuhan. (2) Kerjasama, kemampuan suatu pendi-dikan tinggi dalam bekerjasama dengan komunitas di luarnya. (3) Teknologi infor-masi, yang dapat meningkatkan proses pembelajaran dalam mentransformasikan kurikulum. (4) Internasionalisasi kurikulum, yang didefinisikan Knight \& de Wit, sebagai the process of integrating an international/ intercultural dimentions into the teaching, reseach and service functions of institution....yang diwujudkan dalam studi banding international, saling pengakuan - kesepakatan, dan pendidikan transnasional.

Boediono, \& Umar (1998), mencontohkan lima kurikulum international.

(a) Franchise, yakni penyelenggaraan satu atau lebih program studi oleh suatu universitas atas ijin pihak universitas lainnya.

(b) Artikulasi, yakni pengakuan sebagian program studi universitas lain di luar nege-ri sebagai bagian kredit yang diperlukan di suatu program studi di universitasnya.

(c) Twinning, yakni joint program dua universitas di negara yang berbeda.

(d) Corporate programs, yakni program pendidikan yang ditawarkan suatu perusa-haan besar, yang kreditnya diakui oleh suatu universitas tertentu, sering kali menyangkut beberapa universitas.

(e) Distance education, yakni program pendidikan yang dilaksanakan lintas negara, 
melalui penggunaan satelit, komputer, korespondensi dan media teknologi lain.

Mengacu pada perkembangan PT selama ini parameter relevansi yang patut digunakan adalah imployability. Beberapa kondisi dalam konteks imployability adalah sebagai berikut.

1) Ketidaksesuaian program studi dengan lapangan kerja yang tersedia, sehubungan dengan belum maksimalnya peran link and match sebagai salah satu alternatif pendayagunaan lulusan pendidikan tinggi (Harsono, 1998) yang diperkuat oleh kentalnya fenomena ketenagakerjaan kaum terdidik, dengan banyaknya lulusan PT yang bekerja di luar bidang studinya (Nurusman, 1998).

2) Jumlah output PT lebih besar dari ketersediaan lapangan kerja dengan perbanding-an 150.000: 40.000-60.000 (Alwasilah, 1996).

melakukan

Sehubungan dengan kualitas dan relevansi, BAN-PT perlu akreditasi agar dapat memberikan "pengakuan atas program studi pada perguruan tinggi yang memenuhi standar minimal, sehingga lulusannya dengan persyaratan tertentu dapat melanjutkan pendidikan ke tingkat yang lebih tinggi atau memasuki pendidikan spesialisasi atau menjalankan praktik profesinya" (Kepmendikbud, Nomor 188/U1998: pasal 1; 3). Pemberian pengakuan yang tepat bilamana didasar-kan pada tahap-tahap penilaian yang akurat.

Sehubungan dengan itu, akreditasi perguruan tinggi merupakan pengakuan atas program studi pada perguruan tinggi dalam konteks pengawasan mutu dan efisi-ensi perguruan tinggi yang semestinya (PP No. 30 tahun 1990) dilakukan menteri. Dalam hal tersebut, BAN-PT membantu Menteri Pendidikan Nasional dalam

fungsinya (Depdiknas BAN-PT, 2000a: 4).

Menurut Suhendro (1998a), BAN-PT dipersiapkan sejak tahun 1991 sampai 1993, dengan mengirimkan ahli ke luar negeri untuk penyusunan kriteria. Pemben-tukannya dilakukan tahun 1994 (Kepmendikbud nomor 0326/U/1994, tanggal 15 Desember, dan Nomor 224/U/1995, tanggal 28 Juli). Dengan keanggotaan seperti yang ditentukan Kepmendikbud Nomor 0327/P/1994, tanggal 15 Desember, badan ini kemudian mulai merumuskan kriteria tahun 1996 (Depdiknas BAN-PT. 2000a).

Ada dua sasaran akreditasi PT. Pertama, sebagai salah satu bentuk penilaian kemampuan PT melaksanakan pendidikan. Kedua, sebagai instrumen bagi perguruan tinggi yang bersangkutan untuk menilai 
dirinya sendiri (Suhendro, 1998a). Pencapai-an kedua sasaran tersebut dapat menghindari faktor yang mungkin merugikan.

Dengan kemampuan menggambarkan keadaan PT secara nyata, akreditasi memiliki implikasi-implikasi berikut.

1. Masyarakat dapat menentukan pilihan secara akurat (dapat menghindari kerugian).

2. PT dapat melakukan program pengembangan dan pembinaan secara efektif.

3. Pemerintah dapat memprogramkan bantuan yang dibutuhkan perguruan tinggi.

Manfaat lebih jauh adalah pendistribusian tanggung jawab pembinaan PT yang belum terakreditasi lebih efektif dengan cara mewajibkan program studi katego-ri A, membina program studi yang sama di perguruan tinggi lain (Depdiknas BAN-PT. 2000a). Sedangkan perguruan tinggi yang tidak mampu meningkatkan diri secara alamiah akan mati karena ditinggalkan masyarakat.

Pada prinsipnya, hasil akreditasi menjadi pendorong bagi perguruan tinggi melakukan analisis lingkungan secara berkala untuk mencermati: (1) kekuatan dan kelemahan lingkungan internal, (2), peluang dan tantangan lingkungan eksternal melalui analisis SWOT (Senat IKIP Malang, 1997; O’Connor, 1993). Hal tersebut penting, mengingat lingkungan perguruan tinggi paling mudah berubah sehingga populer sebagai Environmental vulnerability (Peterson, 1986: 13). Dikaitkan aspek pengetahuan yang harus direfleksi dalam missi universitas, dimana "the acquisition of knowledge is the mission of research; the transmission of knowledge is the mission of teaching; and the apllication of knowledge is the mission of public service" (Perkins, 1966: 10), analisis lingkungan semakin penting untuk pengembangan PT.

Dalam konteks pembinaan pengembangan tersebut, BAN-PT merumuskan kriteria yang menjadi standar akreditasi program studi S1 dalam tiga komponen (Depdikbud BAN, 1997; Depdiknas, 2000a:18; dan Depdiknas BAN, 2000c) dengan indikator berikut.

1. Masukan: (1) mahasiswa, (2) tenaga, (3) sarana/ prasarana, (4) kurikulum.

2. Proses: (5) pengelolaan lembaga, (6) pengelolaan program, (7) pengelolaan pembelajaran dan (8) evaluasi.

3. Keluaran, dengan indikator (9) hasil kinerja.

Setiap indikator dirumuskan dalam beberapa pertanyaan, sehingga seluruh pertanyaan berjumlah 56 butir yang digolongkan dalam pertanyaan yang 
bersifat evaluasi, dan yang mengarah pada pembinaan (Depdiknas BANPT, 2000a).

Langkah program akreditasi selanjutnya: (1) melakukan persiapan pengganda-an, dan pengiriman borang kepada perguruan tinggi yang siap diakre-ditasi); (2) pengisian borang (oleh program studi yang akan diakreditasi), (3) penilaian borang; (4) visitasi; (5) pengambilan keputusan tentang hasil akreditasi (Depdiknas BAN-PT, 2000c: ii \& 1). Menurut Sonhadji, 2000: 4), secara rinci, ada delapan keseluruhan langkah prosedur akreditasi.

1. Penyiapan/pengiriman borang dari Sekretariat BAN-PT ke program studi.

2. Pengisian dan pengiriman kembali borng oleh program studi.

3. Verifikasi/ penyusunan profil sementara program studi oleh Sekretariat BAN-PPT.

4. Penyusunan profil I dari profil sementara program studi melalui pertimbangan pakar/ panelis.

5. Visitasi program studi oleh Tim Assessor, dengan supervisi BAN Pleno.

6. Penyesuaian profil II oleh Sekretariat BAN-PT.

7. Perumusan rekomendasi oleh Tim Perumus.

8. Pembuatan keputusan akreditasi oleh BAN Pleno.

Keputusan penilaian, dilakukan dalam tiga tahap, yakni: (1) penyesuaian profil II oleh Sekretariat BAN-PT, berdasarkan hasil laporan visitasi yang disepakati pimpinan program studi, (2) perumusan rekomendasi oleh Tim Perumus, (3) pembu-atan keputusan akreditasi oleh BAN Pleno. Penetapan tingkat akreditas didasarkan pada pencapaian jumlah bobot kriteria yang menjadi standar. Program studi pada peringkat A (baik sekali) mempunyai nilai 601-700, peringkat B bernilai 501-600, peringkat $\mathrm{C}$ bernilai $401-500$, dan peringkat $\mathrm{D}$ bernilai 400 kebawah (Kepmendikbud No. 188/U/1998: pasal 4). Kemudian hasil keputusan dilegalisasi dengan Surat Keputusan (Menteri Pendidikan Nasional atau BAN-PT) yang dikirimkan ke setiap program studi yang telah diakreditasi.

Untuk sampai pada keputusan, tim kerja BAN-PT dilengkapi alat pengumpul data. Penggunaan alat berupa: (1) daftar isian berupa borang, (2) observasi, dan (3) interview sangat menentukan keefektivan kinerja, yakni ketepatan BAN-PT untuk meningkatkan kualitas dan relevansi program studi yang diakreditasi. Sedangkan kinerja adalah unjuk kerja sebagai hasil interaksi kemampuan dan usaha tim BAN-PT (faktor 
internal) dengan faktor iksternal, yakni tingkat kemudahan kerja, kerja sama, dan sifat kepemimpinan perguruan tinggi yang diakreditasi (Bateman, et al. 1988).

Mengiringi tugas yang telah dijalankannya, kegiatan BAN-PT perlu dikaji untuk mengukur kinerjanya. Selanjutnya, suara sumbang yang terlontar sebagai pernyataan kritik terhadap hasil akreditasi bidang studi telah mengilhalmi timbulnya keinginan untuk berpartisipasi dalam kajian ini.

\section{METODE ANALISIS}

Analisis menggunakan pendekatan kualitatif, dengan maksud mendeskripsi-kan kajian pelaksanaan akreditasi yang dilakukan BAN-PT (Bogdan, \& Biklen, 1982; \& Bryman, 1993). Sedangkan pengumpulan data menggunakan teknik dekumentasi penyelenggaraan akreditasi dan komunikasi langsung.

Untuk menghasilkan kritisi, kajian dilakukan melalui tahap-tahap berikut.

(1) Mempelajari kriteria, kemudian menghubungkannya dengan tuntutan kualitas.

(2) Mempelajari cara dan proses pengisian borang (kelengkapan petunjuk, isi dan waktu), kemudian mengkaji peluang yang mungkin mengurangi atau meningkat-kan makna atau filosofis yang mendasarinya.

(3) Mempelajari visitasi, kemudian membandingkan waktu yang tersedia dengan

kegiatan dan alat yang ditetapkan.

(4) Mempelajari hasil akreditasi melalui dekumen: (1) isian borang program studi S1

(dilengkapi protefolio); (2) hasil akreditasi I dan II (Direktori hasil akreditasi program studi jenjang S1 tahun 2000, dan Direktori akreditasi program studi 2000 perguruan tinggi negeri).

Selanjutnya, untuk menjamin keabsahan hasil analisis, penulis menempuh beberapa cara, yakni: meminta pendapat para ahli (anggota tim BAN-PT), menerap-kan teknik trianggulasi sumber, metode, dan teori menurut Denzin (Moleong, 1991), atau penerapan beberapa (multiple) pilihan metode, assessor (penilai), satuan data, dan teori (Brannen, 1993). 


\section{HASIL ANALISIS}

1. Secara kuantitas, ternyata BAN-PT tidak dapat mencapai jumlah program studi yang menjadi target kegiatan akreditasi.

2. Secara kuantitas jumlah program studi yang meningkat setelah akreditasi (kedua) jauh lebih banyak dari yang mengalami kemunduran dan stagnasi.

3. Secara kuantitas waktu yang dialokasikan belum seimbang. Ternyata, penjad-walan waktu dalam tahap-tahap kegiatan kurang memperhatikan kebutuhan, sehingga penyelenggaraan akreditasi kurang maksimal.

4. Secara kualitas, komponen penilaian yang digunakan untuk standar sudah cukup memadai, namum sumber dana dan keuangan sebagai hal yang sangat urgen dengan input, proses dan output masih di kesampingkan.

5. Secara kualitas, reputasi akademik dosen (sebagai indikator ketenagaan) belum diperhitungkan dan diakui secara adil.

6. Secara kualitas, indikator ketenagaan lebih ditekankan pada aspek dosen, sehingga perhatiannya terhadap tenaga manajemen administratif sangat minim.

7. Secara kualitas, penetapan komposisi keanggotaan tim dilakukan secara me-madai. Begitu pula cara penseleksian anggota sangat memungkinkan mening-katnya peran variabel yang mempengaruhi komitmen fungsi pembinaan.

8. Walaupun secara kualitas, pemilihan teknik dan alat pengukuran sudah sesuai dengan data yang dibutuhkan, namun secara faktual tidak berfungsi karena minimnya waktu visitasi yang disediakan untuk observasi dan interview.

\section{PEMBAHASAN}

Kesulitan utama yang dihadapi untuk mencapai target program studi yang menjadi sasaran akreditasi adalah jumlahnya yang sangat besar. Sampai tahun 1985 jumlah perguruan tinggi sudah mencapai 1.209 perguruan tinggi. Terdiri dari: 29 Uni-versitas dan 10 IKIP Negeri (berdiri dasawarsa 1950-1970), 1.170 PTS (251 Univer-sitas, 47 Institut, 452 Sekolah tinggi, 8 Politeknik, dan 382 Akademi), berkembang sejak 1980Juni 1985 (Suhendro, 1996). Sampai 2001, jumlah seluruh PT yang akan diakreditasi lebih dari 2.379 .

Kemudian, dari 1500 program studi yang diprogramkan tahun 1996/1997, hanya 1357 yang dapat diakreditasi. Sedangkan 2000 program studi yang ditargetkan tahun 1997/1998 hanya 1469 program studi yang 
dapat diakreditasi. Dengan kata lain, tahun 1996/1997 BAN-PT dapat mencapai target sebesar 89,5\%, sedangkan tahun 1997/1998 hanya mencapai 73,5\% (Depdiknas BAN-PT, 2000a). Jelas bahwa dalam lima tahun pertama, BAN-PT tidak dapat mengakreditasi semua program studi, dan hal ini dibenarkan oleh assessor. (wawancara, 18 November 2002). Beratnya beban BAN-PT semakin bertambah karena menurunnya jumlah asesor dari 780 orang tingga menjadi 78 orang (wawancara 21 November 2002).

\begin{tabular}{llccc}
\hline $\begin{array}{l}\text { Perguruan } \\
\text { Tinggi }\end{array}$ & Program Studi & Akreditasi I & $\begin{array}{c}\text { Akreditasi } \\
\text { II }\end{array}$ & $\begin{array}{c}\text { Perubahan } \\
\text { Kualitas }\end{array}$ \\
\hline Universitas & 1. Biologi & B & B & Tetap \\
Airlangga & 1. Akuntansi & B & A & Naik1 level \\
& 2. Pend. Dokter G. & B & A & Naik1 level \\
& 4. Kimia & B & B & Tetap \\
& 5. Matematika & B & B & Tetap \\
\hline Universitas & 1. Teknik Kimia & B & A & Naik 1 level \\
Indonesia & 2. Farmasi & B & A & Naik1 level \\
& 3. Sastra Jerman & C & B & Naik1 level \\
& 4. Kimia & C & A & Naik 2 level \\
& 5. Fisika & C & A & Naik 2 level \\
\hline Universitas & 1. Pend. PancaSila & B & B & Tetap \\
Negeri & 2. Pend. B.Ind.\& & B & B & Tetap \\
Malang & Daerah. & & & \\
& 3. Pend. B. & B & A & Naik1 level \\
& Inggeris & & & \\
& 4. Pend. Sejarah & B & C & Turun \\
& 5. Pend. & B & A & Naik1 level \\
& Matematika & & & \\
& 6. Pend. Fisika & B & B & Tetap \\
& 7. Pend. Kimia & B & B & Tetap \\
& 8. Pend. Biologi & B & A & Naik1 level \\
& 9. Pend. Eknomi & B & B & Tetap \\
\hline Universitas & 1. Pend. Bahasa & C & B & Naik1 level \\
& Ing. & & & \\
\hline & 2. Ilmu Tanah & C & B & Naik1 level \\
\hline
\end{tabular}


Secara kuantitas jumlah program studi yang meningkat setelah akreditasi (kedua) jauh lebih banyak dari yang mengalami kemunduran dan stagnasi. 21 program studi empat PT dari enam yang diakreditasi ulang, terjadi variasi perubahan kualitas: (1) menurun, satu program studi, (2) tetap, delapan program studi, dan

(3) naik satu tingkat, 10 program studi, dan (4) naik dua tingkat, dua program studi.

Secara kuantitas waktu yang dialokasikan dapat dikatakan belum seimbang. Ternyata, penjadwalan waktu dalam tahap-tahap kegiatan kurang memperhatikan kebutuhan, sehingga penyelenggaraan akreditasi kurang maksimal. Ini terlihat pada jadwal visitasi, dari dua hari kunjungan (visitasi) hanya 6 jam setengah yang dijadwalkan untuk pengumpulan data (Depdiknas, 2000c: 13), dengan alokasi tiga jam untuk penelaahan (konfirmasi isian borang), satu setengah jam wawancara dosen dan mahasiswa, satu setengah jam observasi PBM, fasilitas/ laboratorium/instalasi program studi. Kajian terhadap waktu tersebut adalah sebagai berikut.

a. Menurut interview yang dilakukan dengan unsur program studi, waktu untuk pengisian borang terlalu panjang, sehingga peluang program studi melakukan rekayasa data sangat besar tanpa gugatan mashasiswa yang berkepentingan dengan ujian negara (informan, 6 November 2002).

b. Satu jam alokasi waktu wawancara dengan mahasiswa dan dosen, mustahil dapat menggali informasi yang memadai.

c. Satu setengah jam observasi PBM, fasilitas/laboratorium/instalasi (Depdiknas BAN-PT, 2000a) mustahil mengukur proses pembelajaran. Hal tersebut men-jadi "pertimbangan Accreditation Board for Engineering and Tech-nology (ABET) untuk menempuh mekanisme visitasi yang lama" (Sonhadji, 2000: 7).

Secara kualitas, komponen penilaian yang digunakan untuk standar sudah cukup memadai, namum sumber dana dan keuangan sebagai hal yang sangat urgen terhadap input, proses dan output belum diperhatikan.

Tidak tercantumnya sumber, dan ketersediaan dana, perlu dipertanyakan. Dengan kata lain, Dikti (Depdikbud waktu itu) tidak berkeinginan mendorong dan mengembangkan akuntabilitas PT yang menjadi ciri otonomi. Untuk menunju badan usaha, faktor-faktor learning and growth (pengembangan dan pertumbuhan), internal business process (pelayanan Tri Dharma), customer (masyarakat pengguna), dan financial (keuangan) setiap PT perlu dikembangakan (Kaplan, \& Norton. 1996). 
Dalam konteks pengelolaan lembaga dan pembelajaran, dana menjadi syarat pelayanan dan pembinaan SDM (Peterson, 1986: 113; Sonhadji, 2000: 7), termasuk alokasi dana penelitian. Karena itu, walaupun tidak diminta bukanlan hal yang aneh, jika sebagian besar PT mengemukakan rata-rata biaya (misalnya Rp. 2.000.000,-) untuk meluluskan seorang sarjana pada peta informasi program studi dan direktori akreditasi (Depdikbud BAN-PT, 2000b).

Secara kualitas, reputasi akademik dosen (indikator ketenagaan) belum diperhitungkan dan diakui secara adil. Ketidakadilan nampak pada penetapan mutu/ produktivitas dosen masih belum spesifik. Khususnya, butir borang nomor 45 (pergruan tinggi swasta) yang hanya memperhatikan dosen tetap.

Akibatnya sangat luas. (1) Dosen yang berstatus tidak tetap atau luar biasa tidak akan memperoleh penghargaan, walaupun memiliki reputasi akademik yang luar biasa di PT yang bersangkutan. (2) Dosen tetap PTS yang berstatus PNS di PTN akan mendapat penghargaan reputasi akademik yang setara dengan perguruan tinggi asalnya. (3) Terjadi penghargaan yang sama atas reputasi Dosen yang mengajar pada dua program studi yang berbeda pada fakultas yang sama atau di program studi yang sama pada fakultas yang berbeda.

Dalam pengamatan, kasus ketiga terjadi di PPS-UM. Contoh (1) empat judul penelitian dari seorang Dosen senior program studi BK, dua di antaranya dilaporkan oleh program studi TEP. Contoh (2) 15 judul seorang dosen senior program studi TEP, sembilan di antaranya dilaporkan juga oleh program studi BK (Portefolio Program Studi BK, 19998/1999: 108 \& 119; Portefolio Program Studi TEP, 1998/1999: 112).

Secara kualitas, indikator ketenagaan lebih ditekankan pada aspek dosen, sehingga perhatiannya terhadap tenaga manajemen administratif sangat minim. Hal ini dibuktikan oleh jadwal dan alokasi interview dalam visitasi yang hanya ditujukan pada dosen dan mahasiswa, sehingga tidak mungkin menggambarkan kepuasan karyawan sebagai bagian dalam proses pengelolaan.

Secara kualitas, penetapan komposisi keanggotaan tim dilakukan dengan cara yang memadai. Begitu pula cara penseleksian anggota sangat memungkinkan meningkatnya peran variabel yang mempengaruhi komitmen fungsi pembinaan. Kualitas keanggotaan, secara akademik tidak terlepas dengan relevansi spesifikasi keahlian dengan program studi yang diakreditasi (Depdiknas, 2000). Di samping itu, aspek pertanggungjawaban moral menjadi bagian yang sangat penting. Aspek 
ini terpenuhi bilamana spesifikasi keahlian anggota dilengkapi sifat objektif.

Pengalaman anggota asesor (wawancara, 21 November 2002), menunjukkan adanya keseriusan BAN-PT dalam mempertahankan nilai filosofis akreditasi sebagai pembina. Pertama, cara BAN-PT melakukan seleksi secara ketat, yakni dari 780 orang menjadi 78 orang (tinggal 10\%). Kedua, pengalaman yang diungkapkan oleh asesor dalam menghadapi keingingan pihak perguruan tinggi untuk bargaining yang kurang terpuji, nampaknya lambat laun dapat memperteguh komitmen tim asesor.

Secara kualitas, pemilihan teknik dan alat pengukuran sudah sesuai dengan data yang dibutuhkan. Namun secara nyata, alat yang dipilih tidak berfungsi maksimal, sebab minimnya waktu yang dialokasikan untuk observasi dan interview selama visitasi di lapangan.

\section{PENUTUP}

Pada prinsipnya, tingkat keefektivan akreditasi yang dilakukan BAN-PT, ter-gantung pada keakuratan kriteria sebagai acuan, teknik/alat yang digunakan dan kesempatan yang dialokasikan. Di samping, komitmen asesor yang berperan mulai dari pengumpulan data, penilaian sampai pada pengambilan keputusan final.

Sesuai temuan dan pembahasan, fungsi pembinaan dan peningkatan kualitas PT yang dilaksanakan BAN-PT pada umumnya sudah cukup memadai. Namun, untuk mencapai kinerja maksimal diperlukan upaya untuk mencapai keakuratan standar dan kewajaran tahapan proses pelaksanaannya.

Sehubungan dengan itu, dikemukakan beberapa saran. (1) Alternatif penca-paian target jumlah program studi dapat dilakukan melalui: (a) penambahan frekuensi kegiatan, tanpa menambah anggota asesor; (b) program studi yang baru akan meng-ajukan akreditasi perlu diberikan batas waktu. Jika dalam batas waktu yang diberikan tidak mengajukan, BAN-PT dapat memberikan sanksi bertahap, dari teguran sampai pada publikasi. (2) Untuk keefektivan data, perlu alokasi waktu secara rasional dengan mengurangi waktu pengisian borang dan menambah waktu visitasi. (3) Perlu dicermati indikator kriteria pengukuran yang berkaitan dengan sumber dana, pengelolaan keuangan, penghargaan reputasi akademik dosen. (4) Untuk memahami keefektivan pengelolaan lembaga, tidak cukup jika hanya melibatkan mahasiswa dan dosen, tanpa melibatkan karyawan atau seksi pengelola unit pelayanan. 


\section{KEPUSTAKAAN}

Alwasilah, A. Chaedar. 1996, 19 Oktober. Reformasi Pendidikan Tinggi, Mungkinkah?. Media Indonesia, hlm. VI.

Bateman, Thomas S. (et.al). 1988. "Mengapa" di Balik Kinerja Kerja Individu. Dalam Timpe, A. Dale (Ed.). 1988. Seri Manajemen Sumber Daya Manusia Kinerja. Terjemahan Sofyan Cikmat. 1999. (hlm. 31-46). Jakarta: Alex Media Komputindo.

Bogdan, Robert C., \& Biklen, Sari Knopp. 1982. Qualitative Research. Boston: Allyn and Boston, INC.

Brannen, Julia. 1993. Mixing Methods: Qualitative ad Quantitative Research. Aldershot USA: Avebury.

Boediono dan Umar, Jahja. 1998. International Kurikulum Sebagai Upaya Ikut Ber-peran dalam Komunitas Pendidikan Global. Makalah disajikan dalam Seminar Nasional Relevansi Pendidikan dalam Pemberdayaan Bangsa di Tengah Komu-nitas Global, Lembaga Pengkajian dan Pengembangan Pendidikan Unibaw, Malang, 28 November.

Bryman, Alan. 1993. Quantitative and Qualitative Research: Further Reflections on Their Integration. Dalam Mixing Methods: Quantitative and Qualitative Research. Andershot, USA: Avebury (Hlm. 57-78).

Dardjowidjojo, Soejono. 1998, 13 Januari. Kita dan Mereka dalam Kepangkatan Dosen. Suara Pembaharuan, hlm. II.

Departemen Pendidikan dan Kebudayaan BAN-PT. 1997. Panduan Pengisian Borang Akreditasi Program Studi Jenjang S1. Jakarta.

Departamen Pendidikan Nasional BAN-PT. 2000a. Direktori Hasil Akreditasi Program Studi Jenjang Sarjana (S1). Jakarta.

Departamen Pendidikan Nasional BAN-PT. 2000b. Direktori Akreditasi Program Studi 2000 Perguruan Tinggi Negeri. Jakarta.

Departemen Pendidikan Nasional BAN-PT. 2000c. Pedoman Visitasi Akreditasi Program Studi S1. Jakarta.

Harsono. 1998. Pokok-Pokok Pikiran Tentang Pengembangan Kurikulum Dalam Upaya Meningkatkan Daya Saing Lulusan Dalam Komunitas Global. Makalah disajikan dalam Seminar Nasional 
Relevansi Pendidikan dalam Pemberdayaan Bangsa di Tengah Komunitas Global, Lembaga Pengkajian dan Pengembangan Pendidikan Unibaw, Malang, 28 November.

Harsono, Soni S. 1998, 8 Januari. Pemberdayaan Perguruan Tinggi Kita. Harian Pelita, hlm. IV.

Kaplan, Robert S., \& Norton, David P. 2000. Translating Strategy Into Action The Balanced Srocecard. Boston, Massachusetts: Harvard Business School Press.

Keputusan Menteri Pendidikan dan Kebudayaan Republik Indonesia Nomor 187/U/1998. tentang Badan Akreditasi Nasional Perguruan Tinggi. Jakarta.

Keputusan Menteri Pendidikan dan Kebudayaan Republik Indonesia Nomor 188/U/1998. tentang Akreditasi Program Studi pada Perguruan Tinggi untuk Program Sarjana. Jakarta.

Lampiran Portefolio Program Studi (Laporan Evaluasi-Diri Sebagai Bahan Akreditasi Program Studi) PSSJ BK. 1998/1999. Malang: IKIP Malang.

Lampiran Portefolio Program Studi (Laporan Evaluasi-Diri Sebagai Bahan Akreditasi Program Studi) PSSJ Teknologi Pendidikan. 1998/1999. Malang: IKIP Malang.

Maleong, Lexy J. 1990. Metodologi Penelitian Kualitatif. Bandung: PT Ramada Rosda Karya.

Nurusman, Andi Nurman. 1998, 13 Januari. Pengangguran (Intelektual) di Tengah Krisis. Repu- blika, hlm. VI.

O"Connor, Carol. 1993. The Handbook for Organizational Change, Strategy and Skill for Trainers and developers. London: McGraw Hill Book Company.

Perkins, James A. 1966. The University in Tradition. New Jersey: Princeton Univer-sity Press.

Peterson, Marvin W. 1986. ASHE Reader on Organization and Governance in Higher Education. Lexington, Massachusetts: Ginn Press.

Segereg, G. Wayan. 1997, 17 Juni. Peringkat Universitas di Asia, Kemiskinan Membawa Hikmah. Surabaya Post, hlm. VI. 
Senat IKIP Malang. 1997. Rencana Strategis IKIP Malang Tahun 19972006; Menyosong dan Mengemban Perluasan Mandat Menjadi Universitas Negeri Malang. Malang: IKIP Malang.

Sonhadji, K.H., H.A. 2000. Relevansi BAN-PT Dalam akreditasi Perguruan Tinggi Teknik dengan Kebutuhan Dunia Usaha/Industri. Makalah Disajikan dalam Seminar Fakultas Teknik UM, Malang, 13 November.

Suhendro, Bambang. 1998a, 4 Januari. Mutu Perguruan Tinggi Kita Belum Memuas-kan. Media Indonesia. Hlm. III.

Suhendro, Bambang. 1998b. Relevance of Higher Education, Policy Paper, UNESCO disampaikan dalam Seminar Nasional Relevansi Pendidikan dalam Pemberda-yaan Bangsa di Tengah Komunitas Global yang Diselenggarakan Lembaga Pengkajian dan Pengembangan Pendidikan Unibraw, Malang, 28 November.

Sulistyo, Hermawan. 1997, 23 Juni. Dosen dan Para Peneliti Malas Membaca. Suara Pembaharuan, hlm. II.

Supriyoko, Ki. 1997, 6 Agustus. Rendahnya Kualitas Pendidikan Kita. Bernas, hlm. IV. 